\title{
Investigating links between rainfall variations in the Ogooué River basin and ENSO in the Pacific Ocean over the period 1940-1999
}

\author{
Sakaros Bogning ${ }^{1,6}$, Frédéric Frappart ${ }^{2}$, Gil Mahé ${ }^{3}$, Adrien Paris ${ }^{4}$, Raphael Onguene ${ }^{1}$, Fabien Blarel ${ }^{2}$, \\ Fernando Niño ${ }^{2}$, Jacques Etame ${ }^{5}$, and Jean-Jacques Braun ${ }^{6}$ \\ ${ }^{1}$ Laboratory of Technology and Applied Sciences, University Institute of Technology, \\ P.O. Box 8698 Douala, Cameroon \\ ${ }^{2}$ LEGOS, Université de Toulouse, France, OMP, 14 Av. E. Belin, 31400 Toulouse, France \\ ${ }^{3}$ HydroSciences Montpellier, Université de Montpellier, 300 Av. Pr E. Jeanbrau, Montpellier, France \\ ${ }^{4}$ Collecte Localisation Satellite (CLS), Ramonville-Saint-Agne, 31520 France \\ ${ }^{5}$ Département de Sciences de la Terre, Université de Douala, BP 24157 Douala, Cameroon \\ ${ }^{6}$ LMI DYCOFAC, IRD, BP 1857 Yaoundé, Cameroon \\ Correspondence: Sakaros Bogning (sakarosb@gmail.com)
}

Published: 16 November 2021

\begin{abstract}
This paper investigates links between rainfall variability in the Ogooué River Basin (ORB) and El Niño Southern Oscillation (ENSO) in the Pacific Ocean. Recent hydroclimatology studies of the ORB and surrounding areas resulting in contrasting conclusions about links between rainfall variability and ENSO. Thus, to make the issue clearer, this study investigates the links between ENSO and rainfall in the ORB over the period 1940-1999. The principal component analysis of monthly rainfall in the ORB was done. The temporal mode of the first component corresponds to the interannual variations of rainfall on the ORB. Also, the pattern of the spatial mode of the first component shows that the ORB is a homogeneous hydroclimatic zone. However, no leading mode is significantly correlated to the ENSO index. A cross-wavelet analysis of the time series of basin-scale rainfall and the ENSO index was therefore carried out. The result is a set of periodogram structures corresponding to some ENSO episodes recorded over the study period. And wavelet coherence analysis of both time series confirms that there are significant links between ENSO and rainfall in the ORB.
\end{abstract}

\section{Introduction}

The Ogooué River is about a $1200 \mathrm{~km}$ long stream-flow (Kittel et al., 2018), and the principal river of Gabon in westcentral Africa. The river rises in the Mount Ntalé, situated northwest of the Plateaus Batéké in The Republic of Congo. Its watershed drains more than $70 \%$ of the country of Gabon, with some tributaries reaching neighboring countries of Cameroon, Equatorial Guinea, and The Republic of Congo. This area annually receives large amounts of rainfall (the mean annual precipitation was $1425 \mathrm{~mm}$ between 19401999; Bogning et al., 2021) which leads to about $4750 \mathrm{~m}^{3} / \mathrm{s}$ average annual discharge at Lambaréné, making this river the second-largest of the region by volume discharge, trail- ing only the Congo (Lambert et al., 2015; Mignard et al., 2017).

In recent decades, the Ogooué River Basin (ORB) has been subject to regional climate change in Western Equatorial Africa characterized by a heterogeneous reduction in rainfall and consequently a reduction in runoff (Hua et al., 2016; Nicholson et al., 2018). Among factors of rainfall variability, some authors showed that central Pacific SSTs governed by El Niño Southern Oscillation (ENSO) are highly correlated to rainfall in central Africa (Camberlin et al., 2001; Farnsworth et al., 2011). However, despite the identification of ENSO as one of the leading factors of regional changes in rainfall, very weak correlations were found between rainfall in the ORB and El Niño index (Bogning et al., 
2021). Since these latter correlations suggest poorly known nonlinear ENSO-rainfall relationships in the ORB, the aim of this work is to investigate links between ENSO and rainfall in the ORB between 1940 and 1999, using cross-wavelet analysis.

\section{Data and methods}

\subsection{The Ogooué River}

The ORB is approximately $224000 \mathrm{~km}^{2}, 90 \%$ of which lies within Gabon (Kittel et al., 2018). This basin is located between $9 / 15^{\circ} \mathrm{E}$, and $4^{\circ} \mathrm{S} / 2.5^{\circ} \mathrm{N}$ (Bogning et al., 2018). The ORB is one of the world's best-preserved ecosystems and probably the last remaining witness of the great natural diversity of Central Africa's rainforests. For example, the rural penetration rate in Gabon is about 1 inhabitant per $\mathrm{km}^{2}$ (Braun et al., 2015; Sannier et al., 2016) and many studies report a deforestation rate close to $0 \%$, with even full natural regeneration (Fichet et al., 2014; Sannier et al., 2016). It is also drained by a dense hydrographic network with about one river every $600 \mathrm{~m}$. The main tributaries of the Ogooué River in order of discharge are the Ivindo which flows into the Ogooué from the right bank close to the equator at Kankan and the Ngounié which flows into the Ogooué from the left bank a few dozen kilometers upstream from Lambaréné (see Fig. 1).

The landscape of the Ogooué is mainly mountainous rainforest, although the elevations are not very high with an average height of about $450 \mathrm{~m}$ (see Fig. 1) (Kittel et al., 2018). The coastal part is plain that extends from the river mouth to the Atlantic Ocean for about $100 \mathrm{~km}$ into the mainland and covers the lake area. The second relief is made up of plateaus very often carved by rivers, which covers a very large part of the basin extending northwards over Ogooué-Ivindo, southeast over Haut-Ogooué (the Batéké plateau), southwards over the Ogooué-Lolo and Ngounié regions. The third structure observed on the ORB is the mountainous massifs consisting of mountain ranges, some of which are $1000 \mathrm{~m}$ high, such as the Crystal Mountains, the Chailu massif (Bogning et al., 2021).

\subsection{Datasets}

The rainfall data used in this study are $0.5^{\circ} \times 0.5^{\circ}$ gridded monthly precipitation generated from the reference series inherited from observations of the ORSTOM (Office de la Recherche Scientifique et Technique de l'OutreMer, now Institut de Recherche pour le Développement - IRD) and now on free access at the SIEREM (Système d'Informations Environnementales sur les Ressources en Eau et leur Modélisation) website of Hydrosciences Laboratory Montpellier (Rouché et al., 2010; Dieulin et al., 2019). These data were made available for the entire African continent over a 60-year period (1940-1999) and

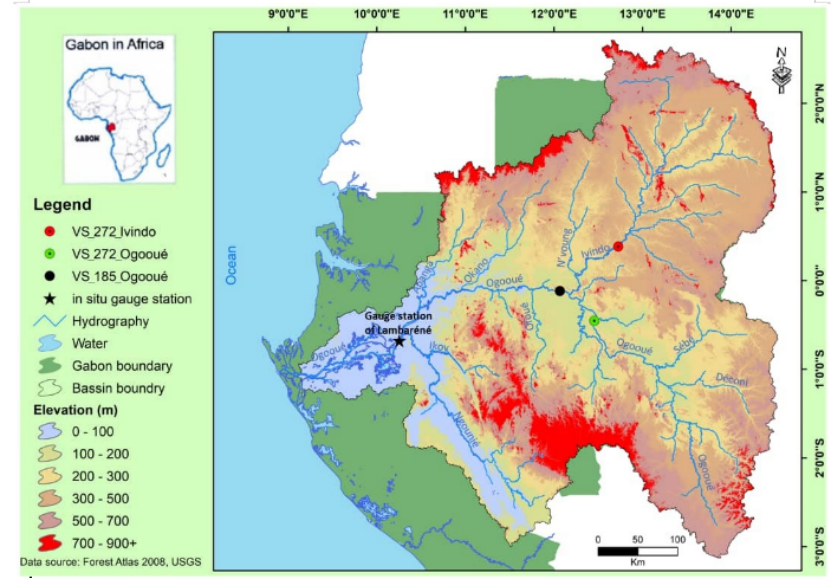

Figure 1. Topography and main rivers of the ORB.

are available at http://www.hydrosciences.fr/sierem/produits/ index.asp?frame=grille (last access: 29 July 2021).

The ENSO index used in this study is Niño 3.4. Monitoring of ENSO conditions primarily focuses on sea surface temperature (SST) anomalies in 4 geographic regions of the equatorial Pacific. The Niño 3.4 region is comprising portions of Niño regions 3 and 4 , from 170 to $120^{\circ} \mathrm{W}$ longitude. In the Niño 3.4 region, SST anomalies equal to or greater than $0.5^{\circ} \mathrm{C}$ in are indicative of ENSO warm phase (El Niño) conditions, while anomalies less than or equal to $-0.5^{\circ} \mathrm{C}$ are associated with cool phase (La Niña) conditions (Bunge and Clarke, 2009; Tippett and L'Heureux, 2020).

\subsection{Methods}

The Empirical Orthogonal Functions (EOF) analysis was carried out to understand the spatial and temporal dynamics of rainfall in the ORB between 1940 and 1999. The correlations between the temporal principal components associated with the first EOFs analysis and the time series of the El Niño index were computed to determine the effects of ENSO on rainfall variations in the ORB. In addition, given the time lags between changes of SSTs in the central Pacific and the appearance of divers ENSO-induced effects in certain regions of the earth's surface (Plisnier et al., 2000; Giannini et al., 2001; Rotstayn et al., 2010; Anyamba et al., 2018; Kolusu et al., 2019), cross-wavelet analysis was applied to the ORB basin-scale time series of rainfall (computed based on Eq. 1; Ramillien et al., 2006) and the El Niño index time series to identify the temporal scales presenting similar variations in these two-variables. It should be noted that the seasonal variability is firstly removed from precipitation data.

$\delta h(t)=\frac{R^{2}}{S} \sum_{j \in S} h\left(\lambda_{j}, \theta_{j}, t\right) \sin \left(\theta_{j}\right) \delta \lambda \delta \theta$

where $h\left(\lambda_{j}, \theta_{j}, t\right)$ is monthly rainfall expressed in mm per month, with $j=1,2,3, \ldots, N, S$ is the area of the basin, $\lambda_{j}$ 
and $\theta_{j}$ are longitude and co-latitude, and are the grid steps in longitude and latitude (generally $\delta \lambda=\delta \theta$ ), $R$ is the mean radius of the Earth $\sim 6371 \mathrm{~km}$.

Wavelet cross-correlation analysis is used to analyze the link between two signals from a common power spectrum. The wavelet transformation technique was introduced into geophysics in the early 1980s by Morlet (1983) for use in seismic research. Since then, the technique has been widely popularized in geosciences (Kumar and Foufoula-Georgiou, 1997; Torrence and Compo, 1998; Torrence and Webster, 1999; Labat et al., 2000; Grinsted et al., 2004; Pozo-Vázquez et al., 2001; Vu et al., 2019; Bogning et al., 2021). Wavelet Cross-correlation and associated coherence and phase, are used to identify scales and temporal locations where two signals co-vary significantly. The cross-wavelet analysis of both time series $X=x\left(t_{i}\right)$ and $Y=y\left(t_{i}\right)$ is formulated as follow:

$W_{j}^{X Y}=\left\langle W_{j}^{X}(s) W_{j}^{Y}(s) *\right\rangle$

where $W_{i}^{X Y}(s)$ is the cross-wavelet transform at time $t_{i}$ on a scale $s$ of the time series $X$ and $Y, W_{i}^{X}(s)$ and $W_{j}^{Y}(s)$ are wavelet transform of time series $X$ and $Y$ respectively.

\section{Results and discussion}

The first two spatial components of the EOF analysis are shown in Fig. 2. The first component explains more about $55.5 \%$ of the total variance and shows the first pattern of visibly homogeneous variation across the basin. The correlation between the temporal component associated with this first mode and the computed Standardized Anomaly Index (SAI) of rainfall in the ORB (not shown because of brevity) gives $R=-0.97, p$ value $=4.72 \times 10^{-39}$. This high correlation denotes a strong link between the SAI and this leading mode, reflecting the abundance of rainfall in the total ORB and suggests homogeneous interannual variability of rainfall in all the ORB. This hydroclimatic homogeneity at the basinscale was not expected because of the strong climatic heterogeneity usually reported in this region (Balas et al., 2007; Nicholson et al., 2018; Nicholson, 2018).

The pattern observed in the second mode of variation shows a dipolar dynamic between the north and south of the basin. Calculation of the correlation between the temporal component associated with this second mode and the SAI applied to precipitation in the boreal summer (JJA) results in $R=-0.44, p$ value $=3.79 \times 10^{-4}$. This phase opposition behavior is singular in the ORB which is a coastal basin with a pure equatorial climate (Lienou et al., 2008). Indeed, this behavior is due to the important occurrences of rains in the northern part of the basin, while in the south one observes the great dry season. The climate of the northern part of the ORB changes from a pure equatorial regime to a northern equatorial regime.

However, the correlations between the temporal components of these two modes and the ENSO result in $R=0.05$,
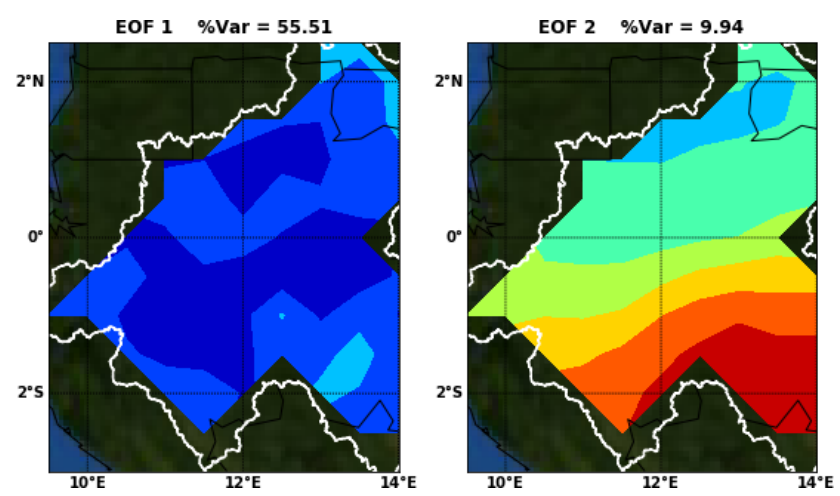

Figure 2. First two components of EOF analysis of rainfall in the ORB from 1940 to 1999.

$p$ value $=0.13$ and $R=0.05, p$ value $=0.10$ for the first and second modes respectively. These correlation values suggest that there are no significant linear relationships between the leading modes of rainfall variabilities in the ORB and ENSO. For further investigation, taking into account the non-linear dynamics of the ENSO phenomenon, the crosswavelet transform of the El Niño time series and that of rainfall estimated based on Eq. (1) has been computed and the result is presented in Fig. 3a. In this figure, many patterns with high power spectra are observed, but those with a significance level of $5 \%$ are surrounded by the black solid lines. They are mainly observed around the 6-month frequency, a little less at one year and a broad and almost restricted structure in the 1980s. These structures of large cross-wavelet power with a $5 \%$ significance level denote either the high wavelet power spectrum of both series or the high wavelet power spectrum of a single time series. It is therefore difficult to know whether there is a link between the two phenomena or not.

The obvious way to provide additional information to determine if both time series are linked or not was the computation of their wavelet coherence. Figure $3 b$ shows the wavelet coherence of ENSO and rainfall in the ORB. In reality, only the simultaneously significant patterns of the cross-wavelet transform and the wavelet coherence of both time series denote links between these phenomena. Around the 6-month frequency, 14 observed patterns are significant in both cross-wavelet transform and wavelet coherence represented contours. These patterns are distributed along the study period such that from 1950 to 1990 , there were three patterns per decade, and the 1940s and 1990s each had only one. At the one-year frequency, two significant patterns were also recorded, one in 1959 and the other in 1965. Also at the 5-year frequency, the high power spectrum of the 1990s observed in the cross-wavelet transform of both time series is partially confirmed by wavelet coherence. These observations confirm links between El Niño in the central Pacific and precipitation in the ORB as reported by some authors in regional studies (Balas et al., 2007; Nicholson and Dezfuli, 

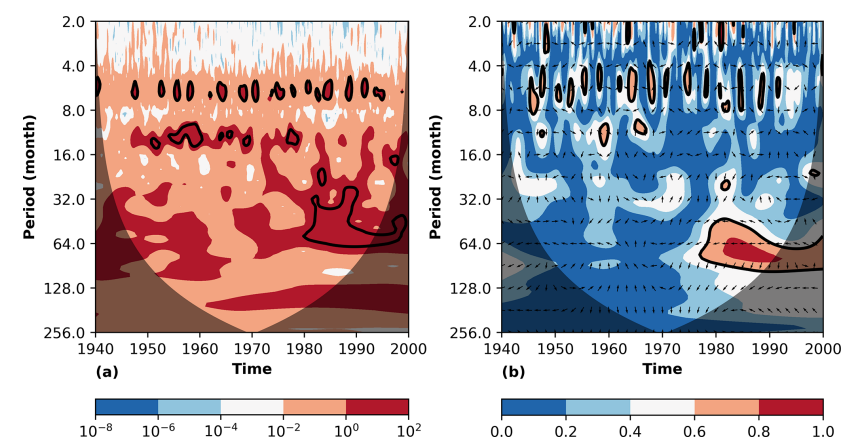

Figure 3. Contours of cross-wavelet transform (a) and wavelet coherence (b) between ENSO and rainfall in the ORB from 1940 to 1999.

2013; Dezfuli and Nicholson, 2013; Maloba Makanga, 2015; Nicholson et al., 2018).

This study shows that instead of the close links generally described between the rainfall in West-central Africa and ENSO (Camberlin et al., 2001; Farnsworth et al., 2011; Nicholson and Dezfuli, 2013; Dezfuli and Nicholson, 2013), the ORB rains are linked to ENSO only during these extreme phases (i.e. El Niño and La Niña). In addition, black arrows indicating the phase difference between both time series in areas of significant common power are not horizontal (see Fig. 3), suggesting time delays between local optima in wavelet transforms of ENSO and rainfall in the Ogooué basin. It means that links found between ENSO and rainfall in the ORB are not cause-and-effect relationships. The observed variation of this phase difference indicates that the time lag between the onset of El Niño (La Niña) in the Pacific Ocean and the decrease (increase) in ORB rainfall is not constant, making it difficult to describe the impacts of ENSO on rainfall in the ORB at seasonal and annual scales like stated in Bogning et al. (2021).

\section{Conclusion}

This study aims to improve the understanding of the link between rainfall in the ORB and the ENSO. It was, therefore, noted that although analysis of rainfall variability in West Equatorial Africa usually pointed out ENSO as a leading factor, its links to rainfall in the ORB are very ambiguous. The linear correlation generally used to highlight the links between rainfall and associated near and remote forcings has proved ineffective to find the ENSO-induced rainfall variability in the ORB. This is because only El Niño-like and La Niña-like effects influence significantly on rainfall of the ORB. This study was able to identify and localize the links between both phenomena in time and frequency thanks to the cross-wavelet analysis.
Code availability. The code is not available due to ongoing scientific research involving this code and additional climate indices.

Data availability. Datasets used in this study are available online. Related links are specified in the text.

Author contributions. SB, FF and GM conceived and designed the study; SB performed data processing with the help of AP, RO, FB, FF, FN and GM; all the authors analyzed the results and contributed to the writing of the paper.

Competing interests. The contact author has declared that neither they nor their co-authors have any competing interests.

Disclaimer. Publisher's note: Copernicus Publications remains neutral with regard to jurisdictional claims in published maps and institutional affiliations.

Special issue statement. This article is part of the special issue "Hydrology of Large River Basins of Africa". It is a result of the 4th International Conference on the "Hydrology of the Great Rivers of Africa", Cotonou, Benin, 13-20 November 2021.

Acknowledgements. The authors want to thank the "Laboratoire Mixte International (LMI) Dynamique des écosystèmes continentaux d'Afrique Centrale en contexte de changements globaux (DYCOFAC)" for its support in the accomplishment of this work and the anonymous reviewers for their helpful comments.

\section{References}

Anyamba, A., Glennie, E., and Small, J.: Teleconnections and Interannual Transitions as Observed in African Vegetation: 20152017, Remote Sensing, 10, 1-16, 2018.

Balas, N., Nicholson, S. E., and Klotter, D.: The relationship of rainfall variability in West Central Africa to sea-surface temperature fluctuations, Int. J. Climatol., 27, 1335-1349, 2007.

Bogning, S., Frappart, F., Blarel, F., Niño, F., Mahé, G., Bricquet, J.-P., Seyler, F., Onguéné, R., Etamé, J., Paiz, M.-C., and Braun, J.-J.: Monitoring Water Levels and Discharges Using Radar Altimetry in an Ungauged River Basin: The Case of the Ogooué, Remote Sensing, 10, 1-18, 2018.

Bogning, S., Frappart, F., Paris, A., Blarel, F., Niño, F., Saux Picart, S., Lanet, P., Seyler, F., Mahé, G., Onguene, R., Bricquet, J.-P., Etame, J., Paiz, M.-C., and Braun, J.-J.: Hydro-climatology study of the Ogooué River basin using hydrological modeling and satellite altimetry, Adv. Space Res., 68, 672-690, 2021.

Bogning, S., Frappart, F., Mahé, G., Niño, F., Paris, A., Sihon, J., Ghomsi, F., Blarel, F., Bricquet, J.-P., Onguene, R., Etame, J., Seyler, F., Paiz, M.-C., and Braun, J.-J.: Long-term Hydrological Variations of the Ogooue River Basin, edited by: Alsdorf Dou- 
glas, Tshimanga Raphael, Moukandi, Guy, Congo Basin Hydrology, Climate, and Biogeochemistry, John Wiley \& Sons, in press, 2021.

Braun, J. J., Jeffery, K., and Koumba Pambo, A. F.: CZO perspective in Central Africa: The Lopé watershed, Lopé National Park, Ogooué River basin, Gabon, 2015.

Bunge, L. and Clarke, A. J.: A Verified Estimation of the El Niño Index Niño-3.4 since 1877, J. Climate, 22, 3979-3992, 2009.

Camberlin, P., Janicot, S., and Poccard, I.: Seasonality and atmospheric dynamics of the teleconnection between African rainfall and tropical sea-surface temperature: Atlantic vs. ENSO, Int. J. Climatol., 21, 8, 973-1005, 2001.

Dezfuli, A. K. and Nicholson, S. E.: The Relationship of Rainfall Variability in Western Equatorial Africa to the Tropical Oceans and Atmospheric Circulation. Part II: The Boreal Autumn, J. Climate, 26, 66-84, 2013.

Dieulin, C., Mahé, G., Paturel, J.-E., Ejjiyar, S., Tramblay, Y., Rouché, N., and EL Mansouri, B.: A New 60-Year 1940/1999 Monthly-Gridded Rainfall Data Set for Africa, Water, 11, 1-17, 2019.

Farnsworth, A., White, E., Williams, C. J. R., Black, E., and Kniveton, D. R.: Understanding the Large Scale Driving Mechanisms of Rainfall Variability over Central Africa, in: African Climate and Climate Change: Physical, Social and Political Perspectives, edited by: Williams, C. J. R. and Kniveton, D. R., Springer Netherlands, Dordrecht, 101-122, 2011.

Fichet, L. V., Sannier, C., Massard, K., Makaga, E., and Seyler, F.: Assessing the Accuracy of Forest Cover Map for 1990, 2000 and 2010 at National Scale in Gabon, IEEE J. Selected Topics in Applied Earth Observation and Remote Sensing, 7, 1346-1356, 2014.

Giannini, A., Chiang, J. C. H., Cane, M. A., Kushnir, Y., and Seager, R.: The ENSO Teleconnection to the Tropical Atlantic Ocean: Contributions of the Remote and Local SSTs to Rainfall Variability in the Tropical Americas, J. Climate, 14, 4530-4544, 2001.

Grinsted, A., Moore, J. C., and Jevrejeva, S.: Application of the cross wavelet transform and wavelet coherence to geophysical time series, Nonlin. Processes Geophys., 11, 561-566, https://doi.org/10.5194/npg-11-561-2004, 2004.

Hua, W., Zhou, L., Chen, H., Nicholson, S. E., Raghavendra, A., and Jiang, Y.: Possible causes of the Central Equatorial African long-term drought, Environ. Res. Lett., 11, 1-13, https://doi.org/10.1088/1748-9326/11/12/124002, 2016.

Kittel, C. M. M., Nielsen, K., Tøttrup, C., and Bauer-Gottwein, P.: Informing a hydrological model of the Ogooué with multimission remote sensing data, Hydrol. Earth Syst. Sci., 22, $1453-$ 1472, https://doi.org/10.5194/hess-22-1453-2018, 2018.

Kolusu, S. R., Shamsudduha, M., Todd, M. C., Taylor, R. G., Seddon, D., Kashaigili, J. J., Ebrahim, G. Y., Cuthbert, M. O., Sorensen, J. P. R., Villholth, K. G., MacDonald, A. M., and MacLeod, D. A.: The El Niño event of 2015-2016: climate anomalies and their impact on groundwater resources in East and Southern Africa, Hydrol. Earth Syst. Sci., 23, 1751-1762, https://doi.org/10.5194/hess-23-1751-2019, 2019.

Kumar, P. and Foufoula-Georgiou, E.: Wavelet analysis for geophysical applications, Rev. Geophys., 35, 385-412, 1997.

Labat, D., Ababou, R., and Mangin, A.: Rainfall-runoff relations for karstic springs. Part II: continuous wavelet and discrete or- thogonal multiresolution analyses, J. Hydrol., 238, 149-178, 2000.

Lambert, T., Darchambeau, F., Bouillon, S., Alhou, B., Mbega, J.D., Teodoru, C. R., Nyoni, F. C., Massicotte, P., and Borges, A. V.: Landscape control on the spatial and temporal variability of chromophoric dissolved organic matter and dissolved organic carbon in large African rivers, Ecosystems, 18, 1224-1239, 2015.

Lienou, G., Mahe, G., Paturel, J. E., Servat, E., Sighomnou, D., Ekodeck, G. E., Dezetter, A., and Dieulin, C.: Evolution des régimes hydrologiques en région équatoriale camerounaise: un impact de la variabilité climatique en Afrique équatoriale?, Hydrol. Sci. J., 53, 789-801, 2008.

Maloba Makanga, J. D.: variabilité pluviométrique de la petite saison sèche au gabon, in: XXVIIIe Colloque de l'Association Internationale de Climatologie, Liège 2015, 6, 2015.

Mignard, S. L.-A., Mulder, T., Martinez, P., Charlier, K., Rossignol, L., and Garlan, T.: Deep-sea terrigenous organic carbon transfer and accumulation: Impact of sea-level variations and sedimentation processes off the Ogooue River (Gabon), Mar. Pet. Geol., 85, 35-53, 2017.

Morlet, J.: Sampling Theory and Wave Propagation, https://doi.org/10.1007/978-3-642-82002-1_12, 1983.

Nicholson, S. E.: The ITCZ and the Seasonal Cycle over Equatorial Africa, B. Am. Meteorol. Soc., 99, 337-348, 2018.

Nicholson, S. E. and Dezfuli, A. K.: The Relationship of Rainfall Variability in Western Equatorial Africa to the Tropical Oceans and Atmospheric Circulation. Part I: The Boreal Spring, J. Climate, 26, 45-65, 2013.

Nicholson, S. E., Funk, C., and Fink, A. H.: Rainfall over the African continent from the 19th through the 21st century, Glob. Planet. Change, 165, 114-127, 2018.

Plisnier, P. D., Serneels, S., and Lambin, E. F.: Impact of ENSO on East African ecosystems: a multivariate analysis based on climate and remote sensing data, Glob. Ecol. Biogeogr., 9, 481-497, 2000.

Pozo-Vázquez, D., Esteban-Parra, M. J., Rodrigo, F. S., and CastroDíez, Y.: A study of NAO variability and its possible non-linear influences on European surface temperature, Clim. Dynam., 17, 701-715, 2001.

Ramillien, G., Frappart, F., Güntner, A., Ngo-Duc, T., Cazenave, A., and Laval, K.: Time variations of the regional evapotranspiration rate from Gravity Recovery and Climate Experiment (GRACE) satellite gravimetry, Water Resour. Res., 42, 1-8, 2006.

Rotstayn, L. D., Collier, M. A., Mitchell, R. M., Qin, Y., Campbell, S. K., and Dravitzki, S. M.: Simulated enhancement of ENSO-related rainfall variability due to Australian dust, Atmos. Chem. Phys., 11, 6575-6592, https://doi.org/10.5194/acp11-6575-2011, 2011.

Rouché, N., Mahé, G., Ardoin-Bardin, S., Brissaud, B., Boyer, J.F., Crès, A., Dieulin, C., Bardin, G., Commelard, G., Dezetter, A., Paturel, J.-E., and Servat, É.: Constitution d'une grille de pluies mensuelles pour l'Afrique (période 1900-2000), https://doi.org/10.1684/sec.2010.0269, 2010.

Sannier, C., McRoberts, R. E., and Fichet, L.-V.: Suitability of Global Forest Change data to report forest cover estimates at national level in Gabon, Remote Sens. Environ., 173, 326-338, 2016. 
Tippett, M. K. and L'Heureux, M. L.: Low-dimensional representations of Niño 3.4 evolution and the spring persistence barrier, Climate and Atmospheric Science, 3, 1-11, 2020.

Torrence, C. and Compo, G. P.: A Practical Guide to Wavelet Analysis, B. Am. Meteorol. Soc., 79, 61-78, 1998.
Torrence, C. and Webster, P. J.: Interdecadal Changes in the ENSOMonsoon System, J. Climate, 12, 2679-2690, 1999.

Vu, P. L., Ha, M. C., Frappart, F., Darrozes, J., and Ramillien, G.: Identifying 2010 Xynthia Storm Signature in GNSS-R-Based Tide Records, Remote Sens., 11, 1-16, 2019. 